\title{
The transnational drivers of populist backlash in Europe: The role of courts
}

\author{
Andrea Pin*
}

(Received 17 December 2018; accepted 20 January 2019)

\begin{abstract}
This Article explores whether and how contemporary constitutionalism may have triggered or facilitated populism and its illiberal agenda. In particular, it focuses on some of the legal doctrines that have characterized the growth of transnational and supranational judicial fora, contrasting them with populism in Europe. The Article first sketches the role of courts in shaping contemporary transnationalism and supranationalism in Europe. Then, it analyzes the role that the ideals of progress and equality have played in the judicialization of pan-European legal culture. Finally, it ponders the consequences of the constitutionalization process of European law for the role of democratically accountable institutions.
\end{abstract}

Keywords: supranational and transnational Courts; democratic deficit; progress; equality; populist reaction

\section{A. Introduction}

Populism is normally perceived as a phenomenon of constitutional retrogression, degeneration, ${ }^{1}$ or backsliding; ${ }^{2}$ liberal democracies consider it a pathology. ${ }^{3}$ It is, however, a largely amorphous phenomenon, ${ }^{4}$ and its contours are hard to grasp. The comparative constitutional studies that focus on general trends-instead of specifics-have encountered difficulty in tracking populist

\footnotetext{
${ }^{*}$ Professor Andrea Pin is an Associate Professor of Comparative Law at the University of Padua. The author wishes to thank the participants of the Symposium on Popular Will, Electoral Democracy and the Courts that was held at the University of Padua on November 16-17, 2017, for their comments on an earlier draft. He also acknowledges that the inaugural conference for the Icon-s Central and Eastern Europe Chapter, held at the Eötvös Loránd University (Budapest) in April 2018, was important to the development of this Article and is therefore deeply thankful to the conference organizers Ester BodnÆr, David Kosar, Zoltán Pozsár-Szentimklósy, and Pál Sonnenved. He finally conveys his gratitude to Marta Cartabia and Ann PowerForde for commenting on different papers on this same subject. Email: andrea.pin@unipd.it.

${ }^{1}$ Richard Albert, Constitutional Amendment and Dismemberment, 43 YAle J. INT'L L. 1 (2018); CAS MUdDE \& CRISTOBAL Rovira Kaltvasser, Populism: A Very SHOrT InTroduction 1 (2017) ("Theoretically, populism is most fundamentally juxtaposed to liberal democracy rather than to democracy per se or to any other model of democracy.").

${ }^{2}$ Théo Fournier, From Rhetoric to Action: A Constitutional Analysis of Populism 12 (EUI WorkING PAPERS 2018/08); see also Tom Ginsburg, Aziz Z. Huq \& Mila Versteeg, The Coming Demise of Liberal Constitutionalism?, 85 U. CHI. L. REV. 239, 244 (2018) ("Democratic backsliding [consists in] neutraliz[ing] the judiciary, dismantle[ing] respect for the rule of law, and restrict[ing] electoral competition.”).

${ }^{3}$ Federico Finchelstein, Returning Populism to History, 21 Constellations 467, 468, 475 (2014); see Nicholas W. Barber, Some Thoughts on Populism and Political Parties, in Symposium, Popular Will, Electoral Democracy and the Courts (2017) (addressing the pathological nature of populism: "Populism is a particular type of constitutional pathology").

${ }^{4}$ David Landau, Populist Constitutions, 85 U. CHI. L. REV. 521, 523 (2018) ("Populism is a fiercely contested concept.").
}

(C) 2019 The Author. Published by Cambridge University Press on behalf of the German Law Journal. This is an Open Access article, distributed under the terms of the Creative Commons Attribution licence (http://creativecommons.org/licenses/by/4.0/), which permits unrestricted re-use, distribution, and reproduction in any medium, provided the original work is properly cited. 
developments worldwide ${ }^{5}$ and determining how they intersect with the winding processes of new democracies. ${ }^{6}$

This Article explores whether and how contemporary constitutionalism may have triggered or facilitated populism, its threats to the rule of law, ${ }^{7}$ and its illiberal agenda. ${ }^{8}$ In particular, it focuses on some of the legal doctrines that have characterized the growth of transnational and supranational judicial fora, contrasting them with populism in Europe. ${ }^{9}$ Without endorsing populism, this Article hypothesizes that populism's mounting wave in Europe can serve as an alert for some diseases that contemporary constitutionalism may have contributed to creating. ${ }^{10}$

Of course, populist rhetoric has many variations. ${ }^{11}$ Populist movements have mushroomed throughout the world: ${ }^{12}$ They have succeeded in Latin America, the Philippines, the Middle East, some Central and Eastern European countries, and have gained momentum in the U.S. and Israel. ${ }^{13}$ It is natural that their agendas overlap only partially. Generally, however, populists claim to propose an alternative to the phenomenon of "global constitutionalism"14 in the legal lingua franca of rights ${ }^{15}$ that has flourished in liberal democracies ${ }^{16}$ and to what they perceive to be the contemporary elite culture "strongly imbued with liberal values of individualism, internationalism, multiculturalism, permissiveness and belief in progress ..."17 They understand themselves as a reaction to such values. As Viktor Orbán, the Prime Minister of the EU member state that seems to have moved most deeply into the realm of constitutional populism so far, ${ }^{18}$ stated in a famous speech in 2014:

\footnotetext{
${ }^{5}$ Renáta Uitz, Can You Tell When an Illiberal Democracy is in the Making? An Appeal to Comparative Constitutional Scholarship from Hungary, 13 INT'L J. CONST. L. 279, 281 (2015) (“[I]n contemporary comparative constitutional scholarship the search for the components of the global constitution detracts attention from the consequences of gradual constitutional transformation and strong confirmation bias steers analysis towards seeing convergence and dialogue and where defiance drives local actors.”).

${ }^{6}$ Bojan Bugarič, A Crisis of Constitutional Democracy in Post-Communist Europe: "Lands In-between" Democracy and Authoritarianism, 13 INT'L J. CoNST. L. 219, 232-33 (2015).

${ }^{7}$ Fournier, supra note 2, at 3.

${ }^{8}$ Kim Lane Scheppele, Autocratic Legalism, 85 U. CHI. L. REv. 545, 548 (2018).

${ }^{9}$ Duane Swank \& Hans-Georg Betz, Globalization, The Welfare State and Right-Wing Populism in Western Europe, 1 Socio-ECONOMIC REv. 215, 215-16 (2003) ("During the past two decades, radical right-wing populist parties have garnered electoral support approaching or exceeding $10 \%$ of the national parliamentary vote in roughly half of the polities of Western Europe.").

${ }^{10}$ Dani Rodrik, What Does a True Populism Look Like? It Looks Like the New Deal, N.Y. Times (Feb. 21, 2018), https://www. nytimes.com/2018/02/21/opinion/populism-new-deal.html; Landau, supra note 4, at 543 ("[P]opulism must be a mirror. It must spur us to confront and respond to the weaknesses of liberal democracy.").

${ }^{11}$ Yascha Mounk, The People vs. Democracy: Why our Freedom is in Danger and How to Save IT 133-81 (2018) (identifying three driving forces behind the disaffection of democracy on a global scale: The role of social media, economic stagnation, and identity).

${ }^{12}$ Landau, supra note 4 , at 521; Fournier, supra note 2, at 1.

${ }^{13}$ Nadiv Mordechay \& Yaniv Roznai, A Jewish and (Declining) Democratic State? Constitutional Retrogression in Israel, 77 MD. L. REv. 244, 244-46 (2017).

${ }^{14}$ Ran Hirschl, Opting Out of “Global Constitutionalism," 12 L. \& Ethics HUM. RTs. 1, 2 (2018).

${ }^{15} I d$. at 3.

${ }^{16}$ Landau, supra note 4, at 529; Aziz Z. Huq, The People Against the Constitution, 116 MiCH. L. REv. 1123, 1124 (2018) (“[P]opulism ... repudiates some or all of the values and institutional commitments underpinning liberal democracy.”).

${ }^{17}$ Margaret Canovan, Trust the People! Populism and the Two Faces of Democracy, 47 PoL. STUD. 2, 4 (1999); see also CAs Mudde, The Ideology of The Extreme Right 172-73 (Manchester Univ. Press 2002) (“All [populist] parties perceive the process of European integration in general, and the abolition of internal borders in particular, as a threat to the character of their own group.").

${ }^{18}$ Albert, supra note 1, at 61 ("For new wave scholars, Hungary is a leading expositor of liberal democratic degeneration."); Stephen Gardbaum, Revolutionary Constitutionalism, 15 In’TL J. Const. L. 173, 174 (2017) (noting that Hungary best exemplifies the practice of "using the constitution-making (and amendment) process as a tool of ordinary rather than higher politics to entrench an existing or newly empowered government's position through measures that concentrate its power and render successful electoral opposition more difficult.").
} 
[The] Hungarian nation is not a simple sum of individuals, but a community that needs to be organized, strengthened and developed, and in this sense, the new state that we are building is an illiberal state, a non-liberal state. It does not deny foundational values of liberalism, as freedom, etc. But it does not make this ideology a central element of state organization, but applies a specific, national, particular approach in its stead. ${ }^{19}$

Orbán accepts the core values of liberalism, although he places them in a different framework and distances himself from some of the values that have driven the construction of pan-European institutions and legal orders:

I will mention another example that is another obstacle of reorganizing the state. When I mention the European Union, I am not doing this because I think it is impossible to build an illiberal nation state within the EU. I think this is possible. Our EU membership does not rule out this option. It is true that many questions formulate, and many conflicts develop ... a lot of battles have to be fought.... Contrary to the liberal state organizational logic of the past twenty years, this is a state organization originating in national interests. Conflicts that erupt are, therefore, not coincidental, do not originate in ignorance (well maybe only sometimes), but these are debates that necessarily accompany the rebuilding and self-definition process of a new state. ${ }^{20}$

Actually, the conflict between national populists and transnational or supranational organizations in Europe seems to be profound. ${ }^{21}$ One of the drivers of populist backlash resides in the urgent conviction that the people and elected institutions get to the center stage of politics and law. This is troubling Europe because the driving forces behind the legal and institutional developments since the end of the Second World War have been organs with only indirect or loose democratic legitimation and accountability. Courts, rather than elected bodies, have often been the pan-European key players.

This Article ultimately takes the view that increasing the democratic accountability of pan-European institutions can only be a palliative cure if the doctrines of their judicial fora are not thoroughly reconsidered. In this respect, populism does more than suggest changes in the existing "institutional arrangement" at the transnational and supranational level: It defies the "deep-seated political culture," that such courts have been shaping for decades now and on which they are premised. ${ }^{22}$

In order to achieve its goal, this Article first sketches the role of courts in shaping contemporary transnationalism and supranationalism in Europe vis-à-vis the rallying lexicon of populism. Then, it analyzes two key components of the ideology behind the judicialization of pan-European legal culture-namely, progress and equality—distilling how these components have unfolded. Finally,

\footnotetext{
${ }^{19}$ Csaba Tóth, Full Text of Viktor Orbán’s Speech at Băile Tuşnad (Tusnádfürdő) of 26 July 2014, BUDAPEST BEACON (July 29, 2014), https://budapestbeacon.com/full-text-of-viktor-orbans-speech-at-baile-tusnad-tusnadfurdo-of-26-july-2014/.

${ }^{20} I d$.

${ }^{21}$ Cas Mudde, Three Decades of Populist Radical Right Parties in Western Europe: So What?, 52 Eur. J. POL. REs. 1, 15 (2013) ("EU's response to the economic crisis has ... exposed the fundamental differences between most elites and most people on the desirability of further European and global integration"); see also Finchelstein, supra note 3, at 469; Mark Tushnet, The Possibility of Illiberal Constitutionalism?, 69 FLA. L. REV. 1367, 1371 (2017) (noting that "liberal constitutionalism might be an aspirational ideal ... illiberal constitutionalism is similarly aspirational, though of course in the other direction."); Ronald F. Inglehart \& Pippa Norris, Trump, Brexit, and the Rise of Populism: Economic Have-Nots and Cultural Backlash, HARVARD Faculty Research Working Paper Series RWP16-0267 (2016) ("We view Populist values as representing one pole of a cultural continuum on which Cosmopolitan Liberal values are located at the opposite pole ....").

${ }^{22}$ Joseph H.H. Weiler, The Political and Legal Culture of European Integration: An Exploratory Essay, 9 INT. J. CONST. L. 678, 694 (2011).
} 
it ponders the consequences of the constitutionalization process of European law for the role of democratically accountable institutions.

\section{B. Taking back control and the role of courts}

One of the rallying cries of populist movements involves giving the center stage to the people vis-à-vis the elites who exercise public powers. The typical anti-elitist and anti-establishment populist narrative is characterized by a high level of political frustration among groups that understand themselves to be social outliers. ${ }^{23}$ It is fueled by masses of "[disgruntled] citizens [who have] $\operatorname{los}[t]$ faith in their system of government" and have voted to "break the system by electing a leader who promises radical change." 24

This insistence on the will of the people is neither distinctly European nor populist. As Michael Sandel noted, "restoring control over the forces that govern our lives and giving people a voice" 25 has also been a priority for the supporters of both Donald Trump in the 2016 U.S. presidential election $^{26}$ and Brexit. ${ }^{27}$ Bringing people to the center stage, however, is problematic for supranational and transnational organizations in Europe. One of the main criticisms these organizations routinely receive is their lack of democratic legitimation. ${ }^{28}$ Although supranational and transnational organizations enact rules and render judicial decisions that impact individuals and States alike, they do not represent people the way domestic institutions do. They affect the lives of those living within their jurisdictions without being fully accountable to the population.

Pan-European institutions have tried to respond to this criticism. ${ }^{29}$ For example, the EU, which has been agonizing over an agenda of democratization for decades now, ${ }^{30}$ has tried to address the perennial want of democratic legitimation through the empowerment of the EU Parliament ${ }^{31}$ and, more recently, the introduction of the "Spitzenkandidaten." ${ }^{32}$ In 2014, each of the EU Parliament's party groups selected its candidate for leadership of the EU Commission before the Parliamentary

\footnotetext{
${ }^{23}$ Symposium, A Continent Divided: Nationalism and the European Union, 32 ConN. J. INT'L L. 310, 311 (2017) (trascribing remarks by Timothy Fisher) [hereinafter Symposium]; Michael Freeden, After the Brexit Referendum: Revisiting Populism as an Ideology, 22 J. Pol. IdeOlogies 1, 5 (2017) ("[A]nti-elitism reflects the direct animosity of populist leaders and politicians towards the establishment elites ....”); see also Inglehart \& Norris, supra note 21, at 4-5.

${ }^{24}$ Kim Lane Scheppele \& Laurent Pech, What is Rule of Law Backsliding?, Verfassungsblog (Mar. 2, 2018), https:// verfassungsblog.de/what-is-rule-of-law-backsliding/ [hereinafter Scheppele \& Pech, What is Rule of Law Backsliding?]; see also Laurent Pech \& Kim Lane Scheppele, Illiberalism Within: Rule of Law Backsliding in the EU, 19 CAMBRIDGE Y.B. EuR. L. STUD. 3, 9 (2017) [hereinafter Pech \& Scheppele, Illiberalism Within: Rule of Law Backsliding in the EU].

${ }^{25}$ Jason Cowley, Michael Sandel: "The Energy of the Brexiteers and Trump is Born of the Failure of Elites," NEW STATESMAN (June 13, 2016), https:/www.newstatesman.com/politics/uk/2016/06/michael-sandel-energy-brexiteers-and-trump-bornfailure-elites.

${ }^{26}$ Samuel Issacharoff, Democracy's Deficits, 85 U. CHI. L. REv. 485, 486 (2018) (“Donald Trump and the Brexit vote are dramatic moments in a populist uprising against the postwar political consensus of liberal rule.").

${ }^{27} I$.; but see Symposium, supra note 23, at 315 (recording Gráinne de Búrca's remarks: "[The] root causes of the Brexit vote are not in some kind of contagious common international backlash against globalization, but really in Britain's distinctive, in its cultural ... historical distinctiveness"); Gráinne de Búrca, Is EU Supranational Governance a Challenge to Liberal Constitutionalism?, 85 U. CHI. L. Rev. 337, 342-43 (2018) (“[I]mportant elements of the illiberal populism evident elsewhere in Europe and beyond were present also in the UK debate and in the size of the vote to leave.").

${ }^{28}$ See Weiler, supra note 22, at 680 (remarking on the EU's lack of democratic legitimation).

${ }^{29}$ Symposium, supra note 23, at 358-59 (transcribing Mark Janis in The Rule of Law Crisis in Poland and Hungary panel).

${ }^{30}$ Joseph H.H. Weiler, Van Gend en Loos: The individual as Subject and Object and the Dilemma of European Legitimacy, 12 InT'L J. CONST. L. 94, 100 (2014) ("In essence, [within EU law] the two primordial features of any functioning democracy are missing - the grand principles of accountability and representation.").

${ }^{31}$ The Lisbon Treaty improved the powers of the Parliament significantly. See Christina Eckes, How the European Parliament's Participation in International Relations Affects the Deep Tissue of the EU's Power Structures, 12 INT'L J. Const. L. 904, 907 (2014).

${ }^{32}$ Spitzenkandidaten: The Story of What Made Last Year's European Elections Different, Eur. PARLIAMENT NEws (May 28 , 2015), http://www.europarl.europa.eu/news/en/headlines/eu-affairs/20150526STO59409/spitzenkandidaten-the-story-ofwhat-made-last-year-s-ep-elections-different.
} 
elections, so citizens could cast their votes in the ballots with a fuller picture of what the EU government would be like.

The democratic character of the EU, however, has been treated by its judicial branch as a reality and not simply as a goal, even in the early stages of European integration. In the 1960s, the European Court of Justice ${ }^{33}$ (ECJ)'s Van Gend en Loos $^{34}$ seminal judgment grounded the direct effect of the European Economic Community laws in the democratic nature of the Community itself. It said that its founding Treaty created a new legal order-an order that was made by the people and for the people, as "the nationals of the states brought together in the Community are called upon to cooperate in the functioning of this Community through the intermediary of the European Parliament...."35

Rooting the new legal order and its direct effect in the involvement of the "nationals of the states" in the legislative process was an astute move. The ECJ needed to stress the democratic basis of the Community because it was construing a daring legal doctrine-one that even the framers of the Treaty had not envisioned. ${ }^{36}$

If one considers the weak powers that the Community gave to the European Parliament in the early 1960s, however, especially in comparison with the constitutional structure that the EU has today, Van Gend en Loos was far from reality. ${ }^{37}$ The Community did not function in a democratic fashion. Nonetheless, in order to bless the Community rules with direct effect, the ECJ found the democratic legitimization it needed in the Parliament.

The democratic problem with transnational and supranational constitutionalism in Europe is also particularly acute in light of the role that the judiciary has played in it. ${ }^{38}$ There is broad consensus that the main drivers of the legal development beyond the state have been judicial. Among the theorizers of this court-centered constitutionalism was Professor Mauro Cappelletti, a towering figure of comparative constitutional law in the second half of the twentieth century. In the mid-1980s, he correctly predicted that the judicial bodies would become the protagonists of the wave of constitutionalism that was emerging in the West and spreading throughout the globe. ${ }^{39}$ Transnational and supranational fora were merging the international success of judicial review in protecting freedoms with the equally strong international call for institutional transcendence beyond the states to create a new wave of constitutionalism. ${ }^{40}$

The late Cappelletti provided his readers with two examples of this new wave of constitutionalism: The ECJ and the European Court of Human Rights (ECHR), ${ }^{41}$ which patrolled the two "inseparable" facets of the post-Second World War's European concerns for human rights and internationalism. $^{42}$

The populist calls to take back control on the one hand, and the attempts to vest transnational and supranational institutions with more democratic robes on the other hand, can be reappraised in light of the central stage that the judiciary has gained. Enhancing the accountability of the

\footnotetext{
${ }^{33}$ This Article will refer to the Court of Justice of the EU (CJEU) when talking about judgments delivered after the former ECJ changed its name, as well as when speaking of the jurisprudence in general that both the ECJ and the CJEU have developed. Similarly, it will speak collectively of the EU when referring to the development of the legal integration within the European Communities and then the EU.

${ }^{34}$ ECJ, Case 26/62, NV Algemene Transport- en Expeditie Onderneming van Gend en Loos v. Netherlands Inland Revenue Administration, ECLI:EU:C:1963:1, Judgement of 5 February 1963.

${ }^{35}$ Van Gend en Loos, Case 26/62 at 12.

${ }^{36}$ Weiler, supra note 30 , at 96.

${ }^{37}$ Joseph H.H. Weiler, Deciphering the Political and Legal DNA of European Integration: An Exploratory Essay, in Philosophical Foundations of European Union LaW 153 (Julie Dickson \& Pavlos Eleftheriadis eds., 2012).

${ }^{38}$ Weiler, supra note 22, at 688 (noting that, as to the democratic deficit, "the [CJEU] as part of the problem").

${ }^{39}$ Mauro Cappelletti, Repudiating Montesquieu? The Expansion and Legitimacy of "Constitutional Justice," 35 CATH. U.L. REV. 1, 6, 20 (1985).

${ }^{40}$ See also Michel Rosenfeld, Is Global Constitutionalism Meaningful or Desirable?, 25 EUR. J. INT'L L. 177, 178 (2014).

${ }^{41}$ Cappelletti, supra note 39, at 20, 22.

${ }^{42}$ Marco Duranti, The Conservative Human Rights Revolution 345 (2017).
} 
institutions beyond the state might be not enough to respond to the democratic call, as the patterns of transnational and supranational legal development are located in the judiciary. Imbibing the EU and the Council of Europe's institutions with democratic mechanisms ${ }^{43}$ may not serve the cause of bringing the people of Europe to the center stage if this path is taken by courts. More specifically, the efforts to democratize the EU further in order to regain popularity seem doomed to fail—as the longstanding, unsuccessful "struggles to connect [the Parliament] to its electorate" 44 confirm-if the legal development at the EU level is first and foremost a matter for unelected institutions, such as its court. ${ }^{45}$ The lack of democratic legitimation of its political branch is not totally resolvable through institutional reforms. Part of the response to the populist complaints must be theoretical and judicial.

Two core components of the legal culture under which transnational and supranational courts operate in Europe are the ideas of progress and equality. The way European transnationalism and supranationalism is understood today, especially at the judicial level, deprives the debates over the democratization of pan-continental institutions of much of their significance.

\section{Democracy and progress}

The Council of Europe and the European Union are both committed to legal and political projects that unfold incrementally. This is no surprise, as they both have drawn inspiration from international law and its optimistically ${ }^{46}$ progressive reading of history. ${ }^{47}$ They align themselves to Western mainstream culture ${ }^{48}$ and see the European legal scenario achieving greater and higher levels of respect for human rights, stronger democratic culture, and widespread adherence to the rule of law through the passing of time. ${ }^{49}$ This approach sees legal development as an incremental, broadly foreseeable process which time unveils. The ECHR and the CJEU's case law have both confirmed this belief by each shaping a distinctive judicial doctrine.

The ECHR does not merely patrol the Convention for the Protection of Human Rights and Fundamental Freedoms (the Convention). It famously expands its scope and meaning by interpreting the Convention as a living instrument, ${ }^{50}$ a metaphor that sees human rights as ever-expanding. ${ }^{51}$ The overarching idea behind the living instrument approach is that the passage

\footnotetext{
${ }^{43}$ Thomas Kleinlein, Consensus and Contestability: The ECtHR and the Combined Potential of European Consensus and Procedural Rationality Control, 28 EUR. J. INT'L L. 871, 884 (2017) (identifying a problem of “democratic legitimation" also for the ECHR).

${ }^{44}$ Eckes, supra note 31, at 918 \& n. 80; see also JHHW, Fateful Elections? Investing in the Future of Europe, 12 INT'L J. CONST. L. 273, 275 (2014) (" $[\mathrm{T}]$ he more powers the European Parliament has gained, the greater popular indifference toward it seems to have developed.").

${ }^{45}$ Symposium, supra note 23, at 325 (transcribing the comments of Peter Lindseth).

${ }^{46}$ See Ginsburg, Huq \& Versteeg, supra note 2, at 253 (regarding the optimism "on behalf of liberal constitutionalism").

${ }^{47}$ See Thomas Skouteris, The Idea of Progress, in The Oxford HANDbooK of The TheOry of International Law 939 (Anne Orford, Florian Hoffman eds., 2016) (regarding the relationship between international law and the idea of progress); see also Armin von Bogdandy, The Transformation of European Law: The Reformed Concept and Its Quest for Comparison, MAX PlanCK RESEARCH SERIES No. 2016-14 5 (2016); Jochen von Bernstorff, International Legal Scholarship as a Cooling Medium in International Law and Politics, 25 Eur. J. INT'L L. 977, 978, 983 (2015); Tilmann Altwicker \& Oliver Diggelmann, How is Progress Constructed in International Legal Scholarship?, 25 EUR. J. INT'L L. 425, 425-26 (2014).

${ }^{48}$ Edward Luce, The Retreat of Western Liberalism 4, 9 (2017).

${ }^{49}$ Id.

${ }^{50}$ Tyrer v. United Kingdom, App. No. 5856/72, para. 31 (Apr. 25, 1978), http://hudoc.echr.coe.int/.

${ }^{51}$ George Letsas, Strasbourg's Interpretive Ethic: Lessons for the International Lawyer, 21 EUR. J. INT'L L. 509,535 (2010) (“T $\mathrm{T}]$ he purpose of human rights courts is to develop, through interpretation, a moral conception of what these fundamental rights are. It is to discover, over time and through persuasive moral argument, the moral truth about these fundamental rights."); see also Kleinlein, supra note 43, at 887 (regarding the idea of "progress" behind the usage of the concept of "consensus" to expand and adjourn the meaning of the ECHR).
} 
of time is good for human rights, to the extent that "a failure ... to maintain a dynamic and evolutive approach would risk rendering [the ECHR] a bar to reform or improvement." 52

Along these same lines runs the CJEU's perspective on legal development, which has been knitting together an "ever-closer [U]nion" through its progressive jurisprudence. ${ }^{53}$ More precisely, the goal of legal integration among the member states has bolstered the CJEU's adoption of the teleological interpretation of EU law. ${ }^{54}$ This interpretive pattern has led its judges to choose, among many plausible interpretations of a rule, the one that best meets the needs of legal integration.

Although the CJEU interprets EU regulations, it actually pushes the integration further, so much so that it has been able to bring many state powers under the control of the EU before legal texts conferred them to the EU. ${ }^{55}$ EU lawyers have prepared the ground for this interpretative pattern, as they have "cultivated an ethos in which the transfer of competence to the European level is regarded as a good thing per se," ${ }^{56}$ without requiring any type of political decision. ${ }^{57}$

The progress-bound judicial reasoning of the two courts is rooted in the belief that democracy, rule of law, and human rights consolidate through time rather than roll back, and that this process leads to stronger forms of legal integration within the European supranational legal order. States that reach a satisfactory level of respect for the basic values of constitutionalism are not supposed to backslide away from constitutionalism; they are expected to solidify their relations. The two courts operate as if the line of constitutional progress were unidirectional.

This belief in the unidirectionality of constitutional developments informs the very mechanisms that patrol state membership to the EU, both before and after the accession. The process of accession to the EU routinely involves the institutions of the EU and Council of Europe and entails a quarantine during which the applicant State is subject to close scrutiny in order to verify its compliance with EU core principles. This approach has been in place since before the introduction of the so-called "Copenhagen Criteria," which crystallized the membership's checklist. The EU has constantly subjected State candidates to a thorough check before accepting them into the EU. ${ }^{58}$

Keeping the changing behaviors of national institutions under the radar of the EU after they enter the club, however, has constantly posed far greater legal and conceptual difficulties to the $\mathrm{EU},{ }^{59}$ as the debates and doubts on the measures against the recent legal developments in Hungary and Poland have recently confirmed. ${ }^{60}$ The TEU's Article 7 of the Treaty on European Union (TEU) - which the EU introduced in part to address the possibility that an Eastern Member State might derail from EU core values ${ }^{61}$ - theoretically should patrol such crises. But both the EU's hesitations in enacting such a nuclear option, ${ }^{62}$ which lasted for a

\footnotetext{
${ }^{52}$ Scoppola v. Italy (No. 2), App. No. 10249/03, para. 104 (Sept. 17, 2009). http://hudoc.echr.coe.int/.

${ }^{53}$ See Caroline Bradley, European (Dis)union: From the 1992 Single Market to Brexit, 25 U. MiAmI INT'L \& COMP. L. REV. 1, 28-29 (2017) (regarding the relationship between the idea of an "ever-closer [U]nion" and progress).

${ }^{54}$ Morten Rasmussen, Rewriting the History of European Public Law: The New Contribution of Historians, 28 AM. U. INT'L L. REV. 1187 (2013); Nial Fennelly, Legal Interpretation at the European Court of Justice, 20 FordHAM INT'L L. REV. 656 (1996).

${ }^{55}$ Koen Lenaerts, Interpretation and the Court of Justice: A Basis for Comparative Reflection, 41 INT'L LAW. 1011, 1030 (2007).

${ }^{56}$ Susanne K. Schmidt, The European Court of Justice and the Policy Process 31 (2018).

${ }^{57}$ Weiler, supra note 22 , at 690 .

${ }^{58}$ De Búrca, supra note 27, at 338 ("The imposition of a form of political conditionality on the process of accession to the European Union had begun in the 1970s and 1980s when Spain, Portugal, and Greece were admitted following periods of domestic dictatorship.").

${ }^{59}$ Mudde \& Kaltwasser, supra note 1, at 115 (“[O]nce a country becomes a member of the club, it has little capacity to monitor its adherence to democracy and the rule of law").

${ }^{60}$ See Wojciech Sadurski, That Other Anniversary (Guest Editorial), 13 Eur. ConsT. L. REV. 417, 421 (2017).

${ }^{61}$ Id. at 419.

${ }^{62}$ European Commission Press Release SPEECH/13/684, State of the Union Address, President José Manuel Durão Barroso (Sept. 11, 2013) (drawing from how the then EU Commission President Barroso called Article 7 in his address).
} 
while, ${ }^{63}$ and the broadly shared consideration of the Article 7 procedure as an "unsuitable instrument to ensure the rule of law," ${ }^{14}$ seem to confirm the progress-bound EU mindset. ${ }^{65}$ Article 7 was a safety valve, good only for hypotheticals, but very unlikely to be deployed: "[T]he assumption has long been that pre-accession checks would guarantee that no country would be admitted to the EU club unless it had already reached the stage of a sustainable democratic regime based on the rule of law, an accomplishment that appeared to preclude backsliding." ${ }^{\prime 66}$ This assumption has finally clashed with the reality of democracy backsliding among EU's state members ${ }^{67}$ and, more generally, with a steady decline of countries' democratic performances worldwide. ${ }^{68}$

One can now re-appreciate the ECHR's doctrine of living instrument and the CJEU's focus on the teleological interpretation of an EU text. ${ }^{69}$ Far from simply being the fruit of the personal ideologies of its members, these theories see history incrementally as the process of a primarily linear development, ${ }^{70}$ which would bring about more human rights protection and benefits in a way that echoed Hegel's reading of history according to Cappelletti. ${ }^{71}$

This ideological framework resonates with the broader comparative legal studies' mainstream. Ugo Mattei has surveyed the academic textbooks on comparative legal systems, ${ }^{72}$ finding that comparatists often embrace an optimistic, progressive reading of history. After the end of the Iron Curtain, some referential textbooks of comparative legal systems removed socialist law from their models altogether, with the additional practical purpose of sparing "the reader some sixty pages[.]" ${ }^{\text {"3 }}$ Socialist law was buried with Soviet Union, however, well before it was dead. At the

\footnotetext{
${ }^{63}$ Armin von Bogdandy, Piotr Bogdanowicz, Iris Canor, Maciej Taborowski \& Matthias Schmidt, A Constitutional Moment for the European Rule of Law - Upcoming Landmark Decisions Concerning the Polish Judiciary, MAX PLANCK RESEARCH PAPER No. 2018-10 2 (2018) (stating that with Poland "European institutions have started to react far more determinedly than in the Hungarian case").

${ }^{64}$ Anne Sanders \& Luc von Danwitz, Selecting Judges in Poland and Germany: Challenges to the Rule of Law in Europe and Propositions for a New Approach to Judicial Legitimacy, 19 GERMAN. L.J. 769, 784 (2018).

${ }^{65}$ Pech \& Scheppele, Illiberalism Within: Rule of Law Backsliding in the EU, supra note 24, at 26 ("[I]t is precisely [the] attempt to spread responsibility for European values across EU institutions that has resulted in the paralysis we have witnessed even while Member States attack the basic values of the European project.").

${ }^{66}$ Scheppele \& Pech, What is Rule of Law Backsliding?, supra note 24; see also European Commission Press Release SPEECH/13/348, Safeguarding the Rule of Law and Solving the "Copenhagen Dilemma": Towards a New EU-Mechanism (Apr. 22, 2013).

${ }^{67}$ Patrick Kingsley, As West Fears the Rise of Autocrats, Hungary Shows What's Possible, N.Y. TimEs (Feb. 10, 2018) https:// www.nytimes.com/2018/02/10/world/europe/hungary-orban-democracy-far-right.html (stating that "the founders of the European Union never considered the possibility that a member state would backslide .... 'We never thought that someone would go the other way ... . It was unthinkable"'); see also Anna Śledzińska-Simon, Constitutional Identity in 3D: A Model of Individual, Relational, and Collective Self and Its Application in Poland, 13 INT'L J. Const. L. 124, 140 (2015) (“Article 6 TEU in the Maastricht Treaty ... assumed that member states are likeminded and share the respect for human dignity, fundamental rights, democracy, the rule of law, and obligations stemming from international law. This like-mindedness was also inscribed in the notion of conditionality of accession of new European democracies."); see also Catarina Botelho, Aspirational Constitutionalism, Social Rights Prolixity and Judicial Activism: Trilogy or Trinity?, 3 Comp. Const. L. Q. 62, 74 (2017) ("Is there a principle of irreversibility of social conquests?"); Ginsburg, Huq \& Versteeg, supra note 2, at 253 (concluding that "there is no foolproof constitutional design that can immunize liberal democracy from the pressures of backsliding" in the light of the turns of constitutional populism).

${ }^{68}$ Ginsburg, Huq \& Versteeg, supra note 2, at 243 (discussing that the survey of the German Bertelsmann Foundation among states worldwide found that "the number of 'highly defective democracies' doubled between 2006 and 2010 ").

${ }^{69}$ See Shai Dothan, The Three Traditional Approaches to Treaty Interpretation: A Current Application to the European Court of Human Rights, 41 Fordham INT'L L. J. (forthcoming 2019) (regarding the nexus between teleological and evolutionary interpretation: "Teleological interpretation is also naturally connected to evolutionary interpretation").

${ }^{70}$ Doreen Lustig \& Joseph H.H. Weiler, Judicial Review in the Contemporary World-Retrospective and Prospective, 16 INT'L J. Const. L. 315, 334 (2018).

${ }^{71}$ Cappelletti, supra note 39, at 31 (noting that modern constitutionalism synthesized natural law and positivism in a Hegelian fashion).

${ }^{72}$ Ugo Mattei, The Cold War and Comparative Law: A Reflection on the Politics of Intellectual Discipline, 65 AM. J. COMP. L. 567 (2017).

${ }^{73} I d$. at 583.
} 
time in which socialist legal tradition was considered extinct and removed from books, over 1.5 billion people worldwide were still under communist rule. ${ }^{74}$ It seems fair to agree with Mattei that almost thirty years ago comparative law celebrated what has been called "the end of history" 75 by removing a specific legal tradition from the bookshelf.

The very idea of progress is now put on trial by populist forces ${ }^{76}$ who feed on a "politics of resentment against a status quo created by incumbent governing elites" operating globally. ${ }^{77}$ This anti-progress resentment is often translated into law and constitutional clauses that aim at resisting the force of progress through the lexicon of identity.

The populist wave is thus exploiting the broader revival of the concept of constitutional identity, ${ }^{78}$ which a smattering of countries have deployed lately to mitigate or shield the enforcement of EU law at the domestic level. ${ }^{79}$ Populists shape their identitarian narratives ${ }^{80}$ along a specific sociocultural agenda. ${ }^{81}$ Their rallying cries emphasize the importance of tradition, ancestry, religion, ${ }^{82}$ and ethnicity, ${ }^{83}$ thereby challenging the very mindset of progress, which is forward-looking. ${ }^{84}$

The conflict between populists and supporters of contemporary constitutionalism is of a theoretical nature. Populists challenge the very idea that the passing of time automatically translates into better laws for a better society, echoing Antonin Scalia's remarks:

[S] ocieties don't always mature. Sometimes they rot. What makes you think that ... human progress is one upwardly inclined plane every day and every way we get better and better? It seems to me that the purpose of the [American] Bill of Rights was to prevent change, not to encourage it and have it written into a Constitution. ${ }^{85}$

The rise of populist narratives celebrating tradition, the preservation of the past, identity, ethnicity, religion, and skepticism toward the future shows, among other things, that a significant number of Europeans do not accept the progress-oriented philosophy of history and of legal theory that has prevailed at the transnational level. Because this aspect of contemporary constitutionalism is not an unquestioned logic anymore, when pan-European courts adopt it, they can operate divisively.

\section{The place that is left to the people}

The two courts' incremental, progressive understanding of history explains their overwhelming role in developing the law. The judiciary has this capacity with little or no help from democratic

\footnotetext{
${ }^{74} I d$. at 585 .

${ }^{75} \mathrm{Id}$. at 590 .

${ }^{76}$ Canovan, supra note 17.

${ }^{77}$ Rosalind Dixon \& Julie Suk, Liberal Constitutionalism and Economic Inequality, 85 U. CHI. L. REV. 369, 373 (2018).

${ }^{78}$ Pietro Faraguna, Constitutional Identity in the EU-A Shield or a Sword?, 18 GERMAN L.J. 1617, 1618 (2018); ŚledzińskaSimon, supra note 67 , at $128,139$.

${ }^{79}$ Faraguna, supra note 78 , at 1629.

${ }^{80}$ Lustig \& Weiler, supra note 70 , at 357.

${ }^{81}$ See Huq, supra note 16 , at 1131 (regarding the sociocultural aspect of populism).

${ }^{82}$ Scheppele, supra note 8 , at 570.

${ }^{83}$ Gábor Halmai, Fidesz and Faith: Ethno-Nationalism in Hungary, Verfassungsblog (June 29, 2018), https:// verfassungsblog.de/fidesz-and-faith-ethno-nationalism-in-hungary/; see also ANDREW ARATO, POST SOVEREIGN CONSTITUTIONAL MAKING 207 (2016).

${ }^{84}$ Canovan, supra note 17 , at 4 .

${ }^{85}$ Full Written Transcript of Scalia-Breyer Debate on Foreign Law, FrEE REPUBLIC (Feb. 27, 2005), http://www.freerepublic. com/focus/news/1352357/posts.
} 
institutions. ${ }^{86}$ The manifestations of popular will are left at the periphery of this process because legal progress consists of the enactment of values and principles that history brings to surface and that the courts expound autonomously. ${ }^{87}$

One can reconsider now the Van Gend en Loos statement that "the nationals of the states brought together in the Community are called upon to cooperate in the functioning of this Community through the intermediary of the European Parliament." 88 This affirmation did not place democracy at the heart of EU mechanisms but was necessary to lay down the foundations for the European Community's legal development through the ECJ. Van Gend en Loos' appeal to democracy had a foundational, rather than functional, role. It rooted the Economic Community's law in the democratic process but actually left the process of legal development in the hands of the ECJ.

Similarly, the doctrine of living instrument places the development of the European Convention from the State members of the European Council and from their democratically elected institutions into the hands of the ECHR, as a brief comparison with the Canadian legal doctrine of the living tree will show. The ECHR's living reading of the Convention resonates with the metaphor ${ }^{89}$ of the Canadian Constitution as a living tree, which the UK Court of Appeal crafted in Edwards v. Canada (Attorney General) ${ }^{90}$ in the 1930s to suggest that the British North America Act provided that country with a legal text that would ensure legal development. This metaphor has come to mean "the practice of interpreting bills of rights as organic documents, such that the meaning of the protected rights and freedoms evolves." ${ }^{\prime 1}$ One of the most contentious aspects of the metaphor in Canada, however, has been who should make the tree grow. ${ }^{92}$ Understanding a constitution as a living tree does not mean, in itself, that courts should make the tree flourish. This task could be left to political majorities, ${ }^{93}$ with courts only working in the margins of this developmental process. This was the view of Edwards itself, ${ }^{94}$ according to the commentators for whom the ruling "did not invite judicial activism." 95

Interestingly, more than 70 years after $E d w a r d s$, while talking about the broadening meaning of the Convention through the interpretation of the ECHR, Lord Bingham of Cornhill made a comparison between the interpretation of the Convention and the "living tree" doctrine of Edwards that had sparked so much controversy and uncertainty about the role of the judiciary. He referred

\footnotetext{
${ }^{86}$ Samuel Issacharoff, supra note 26, at 500 ("The failure of the participatory side of democratic politics ties directly to the difficulties encountered on the deliberative side.").

${ }^{87}$ Eyal Benvenisti \&amp; George W. Downs, The Premises, Assumptions, and Implications of Van Gend en Loos: Viewed from the Perspectives of Democracies and Legitimacy of International Institutions, 25 EUR. J. INT'L L. 85, 102 (2014) (“[J]udicial intervention often pre-empts public deliberation ....”).

${ }^{88}$ Van Gend en Loos, Case 26/62 at 12.

${ }^{89}$ Vicki C. Jackson, Constitutions as "Living Trees"? Comparative Constitutional Law and Interpretive Metaphors, 75 FordHAM L. REV. 921, 954 (2006) (“The 'living tree' is a metaphor, not an interpretive theory that provides a full account, for example, of when some aspect of the constitution is or is not 'frozen."').

${ }^{90}$ Edwards v. Canada (AG) [1930] AC 124 (appeal taken from Can.).

${ }^{91}$ Grant Huscroft, The Trouble of Living Tree Interpretation, 25 U. QUEENSLAND L.J. 3, 4 (2006); see also Jackson, supra note 89 , at 946 ("Flexibility of interpretation ... was linked to the idea of a constitution and to selfgovernance in Canada, under a constitution 'large' enough to allow for its own development.").

${ }^{92} \mathrm{Huscroft}$, supra note 91 , at 4 ("[L]iving tree interpretation is especially problematic because it tends to increase the scope of judicial review by increasing the scope of the protected rights.").

${ }^{93}$ John Finnis, Judicial Law-Making and the 'Living' Instrumentalisation of the ECHR, in LORD SUMPTON AND THE LIMITS OF THE LAW 73, 84 (Richard Ekins, Paul Yowell \& N.W. Barber eds., 2016):

[T]alk of living trees began in Canada as a reference not to any instrument, or even to any set of propositions (such as the Constitution, including conventions, of Canada), but to the political community itself-in that case to the political community, the confederation of Canada, established by the British North America Act 1867.

Id. (emphasis in the original).

${ }^{94}$ See Edwards [1930] AC 124 at 106-107. (showing that Lord Sankey, after talking about the "living tree capable of growth and expansion," added "within natural limits").

${ }^{95}$ Huscroft, supra note 91 , at 6 .
} 
to the Canadian tree metaphor to warn that drawing legal implications from the Convention had to be "carried out with caution, if the risk is to be averted that the contracting parties may, by judicial interpretation, become bound by obligations which they did not expressly accept and might not have been willing to accept." ${ }^{\prime 66}$ In other words, the metaphor of living instrument, and the usage that the ECHR had made of it, ran the risk of overstretching its powers to interpret the Convention.

In a few words, the idea that transnational and supranational institutions are grounded in democracy and respect the will of the people is not fictional-but, neither is it operational. The democratic character of such legal systems arises from their foundations, rather than in how they pursue legal development.

The sub-primary role of democratically elected institutions in the day-to-day activity of developing the law within the EU and in the context of the European Convention provides some foundation for the anti-elitist, populist charges against the supranational European legal orders. ${ }^{97}$

\section{Deliberation v. justification}

At least for a while, "[j]udicial review has been viewed as an important way of redressing some of the 'democracy deficit' within [the EU] ...." ${ }^{98}$ Judicial fora, however, do not make up a viable alternative to democracy. Courts can voice citizen interests and provide "individual redress against powerful and relatively unaccountable institutional forces," 99 but their proceedings do not mirror those taking place within democratically elected bodies. The latter deliberate, whereas courts adjudicate.

As John Rawls put it, judges deal with controversies at a high level of sophistication. Their language and intellectual framework aim to provide their rulings with a justification ${ }^{100}$ and follow a very specific standard of rationality. ${ }^{101}$ They enjoy the reputation of being "model reasongivers" 102 at a time in which reason enjoys an "immense prestige."103

How courts and parliaments rank each other in terms of rationality and primacy is a deeply contentious topic, which is reflected in the different levels of judicial deference to the discretionary choices of politically accountable bodies. On the one hand, the historical controversy ${ }^{104}$ over proportionality scrutiny, which is a staple of transnational and supranational adjudication in Europe ${ }^{105}$ empowers judges to scrutinize the acts of public authorities in depth. On the other hand, the classic British Wednesbury Test ${ }^{106}$ which traditionally entrusts administrative bodies with a high level of discretion, encapsulates the tension between parliaments and courts. ${ }^{107}$

\footnotetext{
${ }^{96}$ Brown v. Stott [2003] 1 AC 681, 703 (UK).

${ }^{97}$ Richard Ekins, Restoring Parliamentary Democracy, 39 CARdozo L. ReV. 997, 1003 (2018) (bemoaning the "little transnational politics; elections to the European Parliament are more often an expression of national political discontent than an act of participation in competitive European politics."); see also Daniel Francis, From Utopia to Apology: The European Union and the Challenge of Liberal Supranationalism, 39 CARDOzO L. REv. 849, 874 (2018).

${ }^{98} \mathrm{Gráinne}$ de Búrca, Proportionality and Wednesbury Unreasonableness: The Influence of European Legal Concepts on UK Law, 3 EUR. PUB. L. 561, 562 (1997).

${ }^{99}$ Id.

${ }^{100}$ John Rawls, The Idea of Public Reason Revisited, 64 U. CHI. L. REv. 765, 768 (1997) (noting that his "idea of public reason applie[d] more strictly to judges than to others").

${ }^{101}$ See Kleinlein, supra note 43, at 889-90 (regarding the typical role of justification in adjudication).

${ }^{102}$ Mathilde Cohen, When Judges Have Reasons Not to Give Reasons: A Comparative Law Approach, 72 WASH. \& LEE L. REV. 483, 498 (2015).

${ }^{103}$ Anthony T. Kronman, Precedent and Tradition, 99 YALE L.J. 1029, 1046 (1990).

${ }^{104}$ De Búrca, supra note 98 , at 564 .

${ }^{105}$ Hirschl, supra note 14, at 3 (labeling it as an "Esperanto-like interpretive method").

${ }^{106}$ Assoc. Provincial Picture Houses, Ltd. v. Wednesbury Corp. [1947] EWCA (Civ) 1, [1948] 1 KB 223 (Eng.).

${ }^{107}$ See Paul P. Craig, Judicial Power, The Judicial Power Project and the UK, 36 U. QuEENSLAND L.J. 355, 365, 373-74 (2017) (regarding the enduring controversy over the proportionality and the Wednesbury tests).
} 
The adoption of proportionality among pan-European Courts, and the British resistance to it, exemplify the clash between the supranational and transnational preference for the virtue of judicial justification against the British sensibility for political deliberation. ${ }^{108}$

The prioritization of justification over deliberation seems to have also contaminated the doctrine of the "margin of appreciation." The ECHR adopted this doctrine to acknowledge that States are better suited to answer their citizens' needs and therefore should have ample leeway to shape their own policies within the limits of the Convention. ${ }^{109}$ Although the margin of appreciation doctrine is able to carve out room for the States and their elected bodies, lately the ECHR has construed it differently. The ECHR has started using it to check whether the State has already scrutinized its own policies through the methods employed by the ECHR itself. ${ }^{110}$ In other words, a State policy is presumptively sound if it has undergone a process of scrutiny at the domestic level that is analogous to what the ECHR adopts. This presumption seems to push the States to adopt doctrines such as proportionality at the domestic level in order to immunize themselves against the ECHR's scrutiny, reinforcing the impression that doctrines springing from the transnational and supranational judiciary are effectively transforming the balance and exercise of powers at the State level.

The judicialization of controversies that the ECHR and the CJEU are promoting comes with a price. As Jeremy Waldron has noted, judges focus on texts, investigate their plausible interpretations, and wrestle with precedent. ${ }^{111}$ Through extremely detailed and technical processes, ${ }^{112}$ they transform the controversies they deal with into materials they can handle, thereby shrinking the complexities of issues before them. ${ }^{113}$

The difference between parliamentary disagreement and judicial disagreement is striking if one considers the structure of judicial opinions. When judges pen separate opinions, they tend to share a common rationality. They are confronted with the same legal arguments, although they may disagree in how to evaluate them. On the contrary, parliament members may use disparate arguments, which are hardly commensurable; and yet they accept this type of extreme disagreement, as their electors do. ${ }^{114}$ Parliaments are loci of "cacophonous disagreement," 115 not just because their members disagree on the bills they vote for or against, but even on the arguments they make. When people deliberate, they operationalize the idea that there are things that should be organized together, ${ }^{116}$ while simultaneously accepting that people can disagree on a substantial number of topics. $^{117}$

\footnotetext{
${ }^{108}$ E.g., James Goodwin, The Last Defence of Wednesbury, 3 PuB. L. 445 (2012).

${ }^{109}$ Steven Greer, The Margin OF Appreciation: Interpretation and Discretion Under the European Convention on Human Rights 7 (2000); Janneke Gerards, Margin of Appreciation and Incrementalism in the Case Law of the European Court of Human Rights, 18 Hum. RTs. L. Rev. 495, 499-500 (2018).

${ }^{110}$ See Oddný Mjöll Arnardóttir, Organised Retreat? The Move from 'Substantive' to 'Procedural' Review in the ECtHR's Case Law on the Margin of Appreciation, EUR. SOC'Y INT'L L. CONF. PAPER SERIES 12 (2015):

[The ECHR] will not perform that task if its assessment of the domestic court's reasoning reveals a conscientious application of the relevant Convention principles ... and a careful weighing of the opposing individual interests under the principle of proportionality. If that is the case, the Strasbourg Court will simply trust the national court for the performance of the in concreto proportionality assessments and not repeat the exercise.

Id.; see also Kleinlein, supra note 43, at 872 ("[T] he [ECHR] grants a broad margin [of appreciation] if the domestic authorities have ... balanced competing interests and fundamental rights diligently.”); Elena ERVAS, LA Tutela DELla LiberTẢ Religiosa da Parte della Corte Europea dei Diritti Dell’uomo e della Corte Suprema Statunitense (2018).

${ }^{111}$ Jeremy Waldron, The Core of the Case Against Judicial Review, 115 YALE L.J. 1346, 1383-84 (2006).

${ }^{112}$ Paul Yowell, Constitutional Rights and Constitutional Design 91-92 (2018).

${ }^{113} I d$. at 91 .

${ }^{114} I d$. at 40.

${ }^{115}$ JerEmy WALDRON, LAW AND DisagreEment 9 (1999).

${ }^{116} \mathrm{Id}$. at 101 .

${ }^{117} \mathrm{Id}$. at 106.
} 
The distance between democratically elected bodies and the judiciary is further aggravated by the language factor. ${ }^{118}$ The technicalities of the law as well as the sharpness and precision of legal concepts are features shared between legislation and case-law. But parliamentary deliberations can host narratives that are more easily accessible to the people, and with which individuals and groups can entertain a dialogue. ${ }^{119}$ Courts sustain themselves with their skill in reasoned judgments, and cannot detach themselves from technicalities without running the risk of imprecision or triviality.

\section{Democracy, equality, and recognition}

Supranational and transnational litigation in Europe has changed over time, thereby also changing the institutional roles. This evolution seems to be particularly visible in the transformation of the value and contours of the principle of equality.

The early era of European supranational institutions was dominated by a limited understanding of equality, during which the ECHR and the ECJ were supposed to behave mainly as nonpartisan umpires and crisis-preventers. The institutions of the Council of Europe created a framework for the peaceful resolution of controversies that placed States of different strengths and sizes on an equal footing. ${ }^{120}$ All Member States were subject to the Convention, and its Commission and the ECHR impartially administered justice and prevented crises. This type of equality, which the Council of Europe guarded closely, operated at the margins of the democratic life of the post-Second World War States. ${ }^{121}$

At the outset, the ECJ decided cases in a scenario that was dominated by the concerns of continental peace ${ }^{122}$ and economic equilibrium. It aimed at creating a free market of goods and services through enforcing market equality among economic providers regardless of their national origin. $^{123}$

Towards the end of the twentieth century, the scenario seemed to simplify and confirm the equalizing approach. When the Iron Curtain dissolved, economic wealth and social development remained high in the European agenda. None other than the late Edward Shevardnadze, once the Minister of Foreign Affairs for the Soviet Union, affirmed that the end of the Eastern Block had pushed the world into a post-ideological dimension. Politics at its core consisted in the distribution of economic resources within the inescapable market system. ${ }^{124}$ To put it like Fukuyama,

\footnotetext{
${ }^{118}$ Michel Rosenfeld, Judicial Politics Versus Ordinary Politics: Is the Constitutional Judge Caught in the Middle?, in JUDICIAL Power: How Constitutional Courts Affect Political Transformations (Christine Landfried ed., forthcoming Feb. 2019).

${ }^{119}$ Erik Longo, The European Citizens' Initiative: Too Much Democracy for EU Polity?, in this issue (calling for the creation of "a pluralistic, civic space of dialogue" within the EU).

${ }^{120}$ Letsas, supra note 51, at 537. (“TT]he ECHR was not originally intended as a means of delivering individual justice to all Europeans, as it now functions, but rather as a means of contributing to the peace of Western Europe in the context of the Cold War.").

${ }^{121}$ Tom Gerald Daly, The Alchemists 111 (2017).

${ }^{122}$ Bradley, supra note 53, at 6-7; see also Gordon Silverstein, Globalization and the Rule of Law: "A Machine that Runs of Itself?", 1 INT'L J. CONST. L. 427, 432 (2003).

${ }^{123}$ Marco Dani, The Rise of the Executive and the Post-Political Drift of European Public Law, 24 IND. J. GLOBAL L. STUD. 399, 405-07 (2017) (sequencing the development of EU law further, identifying an early epoch, within which the ECJ settled mere regulatory disputes, and a later epoch, when it expanded its scope to more social policies).

${ }^{124}$ Francis Fukuyama, The End of History?, 16 NAT'L INT. 3 (1989):

The struggle between two opposing systems is no longer a determining tendency of the present-day era. At the modern stage, the ability to build up material wealth at an accelerated rate on the basis of front-ranking science and high level techniques and technology, and to distribute it fairly, and through joint efforts to restore and protect the resources necessary for mankind's survival acquires decisive importance.

Id. (citing Eduard SheVARdnAdZe, Vestink MinisterstVa InOSTRANNiKH DEL SSSR No. 15 27-46 (1988)); see also Marco Dani, supra note 123 , at $407-13$.
} 
history as we knew it — the one made of wars, ideological rifts, and theories of salvation-was over. $^{125}$

In a context in which the debates were mostly about how best to stimulate the economy and bring outliers into the market, democracy and the popular will may be considered as means to fixed, neutral ends. Here, courts - even pan-European ones- that review popular choices seem to ensure that the policies actually pursue foreordained goals. ${ }^{126}$

How to distribute resources and create economic opportunities is, of course, highly contentious, but it is not necessarily a debate around fundamental values. Even more importantly, it is a topic that invites experts to the discussion more than average citizens. Many issues surrounding social rights, taxes, market economy, and public expenditure may be labeled with the language of "applied deliberations:" They belong to a "process of implementing public values as law."127 On such issues, "[m] ost citizens deliberate relatively little," 128 as these policy aspects "tend to implicate legalistic arcana"129 and are particularly suitable for an expert's scrutiny.

The last twenty years of transnational and supranational litigation seem to have almost revolutionized the scenario in two ways. First, concrete controversies called into question the underlying assumption that a unified social market economy would inevitably bring about more prosperity and job opportunity for EU States and citizens. Second, new types of ideologically loaded controversies reached the two courts.

The pre-2008 crisis judgment that best exemplifies the progress-oriented jurisprudence and its optimistic assumption is probably the 2007 CJEU's Viking judgment. ${ }^{130}$ In Viking, the CJEU justified the limitation on a Finnish ferry crew's collective action against the ferry-owner's aim to reflag the ship in order to reduce salaries, thus making the activity more competitive.

The most telling lines are to be found in Advocate General Miguel Maduro's opinion, which prioritized the right to establishment over the right to collective action under the assumption that this would be conducive to a wealthier Europe and more job opportunities:

Inevitably, the realisation of economic progress through intra-Community trade involves the risk for workers throughout the Community of having to undergo changes of working circumstances or even suffer the loss of their jobs.... [T] he European economic order is firmly anchored in a social contract: workers throughout Europe must accept the recurring negative consequences that are inherent to the common market's creation of increasing prosperity, in exchange for which society must commit itself to the general improvement of their living and working conditions, and to the provision of economic support to those workers who, as a consequence of market forces, come into difficulties. ${ }^{131}$

\footnotetext{
${ }^{125}$ Fukuyama, supra note 124 , at 4 :

What we may be witnessing in not just the end of the Cold War, or the passing of a particular period of post-war history, but the end of history as such: that is, the end point of mankind's ideological evolution and the universalization of Western liberal democracy as the final form of human government.

Id.; see also Matthias Goldmann, The Great Recurrence-Karl Polanyi and the Crises of the European Union, 23 EUR. L. J. 272, 277, 284 (2018) (regarding the relationship between the rhetoric of the "end of history" and the paradigm of economic liberalism).

${ }^{126}$ Patrick J. Deneen, Why Liberalism Failed 155 (2018) (observing generally that "[a]s long as liberal democracy expands 'the empire of liberty,' in the form of expansive rights, power, and wealth, the actual absence of active democratic self-rule is not only an acceptable but a desired end").

${ }^{127}$ Ron Levy, The Deliberative Case for Constitutional Referenda, 16 ELECTION L.J. 213, 215 (2017).

${ }^{128} \mathrm{Id}$.

${ }^{129} \mathrm{Id}$. at 216.

${ }^{130}$ ECJ, Case C-438/05, Int'l Transp. Workers' Fed'n v Viking Line ABP, ECLI:EU:C:2007:772, Judgment of 11 Dec. 2007.

${ }^{131}$ Opinion of Advocate General Maduro at paras. 57-59, Case C-438/05, Int'l Transp. Workers' Fed'n v. Viking Line ABP (May 23, 2007), http://curia.europa.eu/juris/document/document.jsf?text=\&docid=62533\&pageIndex $=0 \& d o c l a n g=e n \& m o d e=$ req\&dir $=\& o c c=$ first $\&$ part $=1 \&$ cid $=9200213$.
} 
Maduro's prioritization of economic rights over social rights ${ }^{132}$ clearly stemmed from the belief that free market and globalization would entail progress and increasing prosperity. In 2007, the CJEU probably thought that Viking was striking a fair balance between the right to collective action and the right to establish an economic undertaking. When the debt crisis hit the EU, Viking was put into question. In the span of a few years, Viking gained the reputation of being the CJEU's equivalent of the early 1905 Lochner judgment, ${ }^{133}$ which epitomized the U.S. Supreme Court's laissez-faire jurisprudence. ${ }^{134}$ Viking did not foresee that the "[g]lobalization of markets. .. generates losses and new economic insecurities for some occupational strata and sectors." ${ }^{35}$ It simply viewed a new economic and labor clash as a momentary economic struggle.

The types of issues now at the forefront push the concept of equality further than in previous decades. ${ }^{136}$ The ECHR was probably the first to heed the call for a new understanding of equality. Thanks to its living instrument doctrine, the ECHR has demonstrated an "increasing sensitivity to issues of nondiscrimination," using it as a prism to address "gender issues, reproductive rights, bioethical problems, the notion and role of the family, law and religion, [and] the protection of ethnic minorities in multicultural contexts" in a rather unprecedented way. ${ }^{137}$

This new wave of intense judicialization of controversies under the prism of equality has sometimes proven to be counterproductive even at achieving a durable peace, which was one of the founding values of the Convention. In 2009, the ECHR struck a blow to the fragile peace in the Balkans. It had to adjudicate whether the rights of Dervo Sejdic and Jacob Finci-two citizens of Bosnia-Herzegovina - to stand for elections had been violated. As members of ethnic minorities - respectively, Jewish and Roma-they could not run for some key institutional posts because Bosnian constitutional provisions reserved those seats to the three biggest national communities-Croatians, Serbians, and Bosniaks. The ECHR found that both applicants had suffered from an inadmissible discrimination under the Convention. ${ }^{138}$

What the ECHR found to be an episode of discrimination was cognizable in a very different light. The Bosnian constitutional system granted the country a fragile peace, precisely because it gave equal status to the three main contending parties that had waged war on each other up until that point. ${ }^{139}$ As Christopher McCrudden and Brendan O'Leary have emphasized, the ECHR failed to consider equality under the prism of the Bosnian Constitution that pacified the region: Namely, it overlooked equality among groups, in order to protect equality among individuals. ${ }^{140}$ The ECHR saw a difficult controversy in the light of individual rights, missing a key component of the issue, and thereby endangering the fate of the Bosnian peace agreements.

The CJEU's docket has also attracted new, more politically-nuanced and controversial cases. Instead of aiming at securing a fair distribution of opportunities and resources, many controversies it deals with now revolve around the politics of recognition of individuals and groups. ${ }^{141}$ Societies diverging deeply_both within themselves and as a whole in terms of lifestyle, values, and principles they want to live by-have reached out to the CJEU to solve their conflicts. Such issues cannot be the object of applied deliberations, around which ordinary people may lack

\footnotetext{
${ }^{132}$ SCHMIDT, supra note 56, at 215 (talking about a "neoliberal bias" that dominated the string of cases of which Viking was a key component).

${ }^{133}$ Lochner v. New York, 198 U.S. 45 (1905).

${ }^{134}$ Danny Nicol, Europe's Lochner Moment, 2 PUB. L. 308 (2011).

${ }^{135}$ Swank \&amp; Betz, supra note 9, at 220.

${ }^{136}$ See Symposium, supra note 23, at 351 (transcribing the words of Pierre Vimont).

${ }^{137}$ Marta Cartabia, The European Court of Human Rights: Judging Nondiscrimination, 9 INT'L J. ConsT. L. 808, 809 (2011).

${ }^{138}$ Sedjic v. Bosnia, 2009-VI Eur. Ct. H.R. 273.

${ }^{139}$ Christopher McCrudden \& Brendan O’Leary, Courts and Consociations, at xvii (2013).

${ }^{140} I d$. at 11 .

${ }^{141}$ Larry Alexander, Brexit and the Future of Liberal Democracy, 39 CARDOzo L. Rev. 845, 847 (2018) (warning about the outer limits of multiculturalism for contemporary societies).
} 
information and competence. They must be subject to "[v]alue deliberation[s]," 142 because they revolve around "foundational interests, commitments, principles, ideologies, and worldviews." 43 Within this new framework, equality is played to expand rights and increase rights holders, rather than to assess whether everyone has access to markets.

Just to name a field that was virtually empty of CJEU's judgments, significant case-law on religious freedom has surfaced between 2017 and 2018, with more controversies on the way. Hot topics include the place of Islam in the public sphere, ${ }^{144}$ the selection and treatment of employees on religious grounds, ${ }^{145}$ state funding of religious schools, ${ }^{146}$ religious databases, ${ }^{147}$ and religious holidays. ${ }^{148}$ Many such cases revolve around the EU prohibition of discrimination. As a result, the CJEU receives growing numbers of requests for rulings that involve extremely sensitive topics, which it must assess through the purportedly neutral lenses of nondiscrimination.

These cases also pose problems for the types of scrutiny the CJEU is familiar with, fueling the anti-EU and the anti-judiciary propaganda of populists. Cases involving multiple rights and interests have been routinely subject to the proportionality test. While many praise the test's transparency and consistency, more critical voices consider it an overly technical instrument that dodges conflicts and flattens values in a way that looks digestible on its face, but actually obliterates the meaning and importance of the values involved. ${ }^{149}$ With a growing docket of controversial cases, the populists' allegations ${ }^{150}$ that the CJEU may simply avoid considering the legal challenges squarely, using multi-phase processes of scrutiny in order to de-politicize the issues it is confronted with, are likely to increase. ${ }^{151}$

The mechanisms that normally trigger the two courts' proceedings can exacerbate the populists' charge that supranational and transnational litigation deprive national communities of their common identities and values. They work by isolating individuals from the collectivities to which they belong. Such opposition is particularly evident in the context of the ECHR's pilot judgment. ${ }^{152}$ After individual applications flooded its docket, the ECHR invented a procedure to investigate whether a domestic rule is intrinsically flawed to the extent that it can cause serial Conventional violations. For States that enjoy a democratic DNA, this process serves as a check on democratic deliberations or decisions made by democratically elected bodies for the sake of protecting individuals. ${ }^{153}$ It pits individuals against collectivities and democratic institutions.

\footnotetext{
${ }^{142}$ Ron Levy, supra note 127 , at 215.

${ }^{143} \mathrm{Id}$.

${ }^{144}$ ECJ, Case C-372/16, Sahyouni v Mamisch, ECLI:EU:C2017:988, Judgment of 20 December 2017 ; ECJ, Case C188/15, Bougnaoui v Micropole, ECLI:EU:C:2017:204, Judgment of 14 March 2017; ECJ, Case C-157/15, Achbita v G4S Secure Solutions, ECLI:EU:C:2017:203, Judgment of 14 March 2017; ECJ, Case C-426/16, Liga van Moskeeën en Islamitische Organisaties Provincie Antwerpen v Vlaams Gewest, ECLI:EU:C:2018:335, Judgment of 29 May 2018.

${ }^{145}$ ECJ, Case C-414/16, Egenberger v. Evangelisches Werk für Diakonie und Entwicklung eV, ECLI:EU:C:2018:257, Judgment of 17 April 2018; Opinion of Advocate General Wathelet, Case C-68/17, IR v. JQ (May 31, 2018), http://curia. europa.eu/juris/document/document.jsf?text $=\&$ docid $=202426 \&$ pageIndex $=0 \&$ doclang $=\mathrm{EN} \& \operatorname{mode}=1 \mathrm{st} \& \mathrm{dir}=\& \mathrm{occ}=$ first $\&$ part $=1 \&$ cid $=12338335$.

${ }^{146}$ ECJ, Case C-74/16, Congregación de Escuelas Pías Provincia Betania v Ayuntamiento de Getafe, ECLI:EU:C:2017:496, Judgment of 27 June 2017.

${ }^{147}$ ECJ, Case C-25/17, Tietosuojavaltuutettu v Jehovah's Witnesses, ECLI:EU:C:2018:551, Judgment of 10 July 2018.

${ }^{148}$ Opinion of Advocate General Bobek, Case C-193/17, Gresco Investigation GmbH v Achatzi (July 25, 2018), http://curia. europa.eu/juris/document/document.jsf?text $=\&$ docid $=204414 \&$ pageIndex $=0 \&$ doclang $=\mathrm{EN} \& \operatorname{mode}=1$ st $\&$ dir $=\& o c c=$ first $\&$ part $=1 \&$ cid $=12338597$.

${ }^{149}$ Toni Marzal, From Hercules to Pareto: Of Bathos, Proportionality, and EU Law, 15 INT'L J. Const. L. 621, 622 (2017).

${ }^{150}$ Canovan, supra note 17, at 6 ("Populists ... denounce ... technicalities that only experts can understand. ").

${ }^{151}$ Marzal, supra note 150 , at 641.

${ }^{152}$ European Court of Human Rights, Rules of the Court, Rule 61 (2018).

${ }^{153}$ Wojciech Sadurski, Partnering with Strasbourg: Constitutionalisation of the European Court of Human Rights, the Accession of Central and East European States to the Council of Europe, and the Idea of Pilot Judgments, 9 HuM. RTs. L. REV. 397, 397-98 (2009).
} 
The CJEU's preliminary ruling procedure has similar characteristics. The mechanism that has made the CJEU so famous and important for the development of legal integration of EU law with domestic law ${ }^{154}$ creates a similar tension between the individual and the collective. This is exemplified when an individual claims that her domestic law or practice conflicts with the freedom she enjoys under EU law. Joseph Weiler notes that:

The situation implicated in preliminary references always posits an individual vindicating a personal, private interest against the public good.... [T] he reality of the situation from a social perspective is that - for good legal reason-the principal artifact of the principle of the rule of law in the thin political space constituted by the Union places the individual at odds with his or her thicker national political space. ${ }^{155}$

Weiler concludes that this mechanism "creates the most effective compliance pull," but, at the same time, "contributes to the national social and political turn against the Union." 156

Pitting the individual against the national community had a certain meaning when the issues at stake were overwhelmingly economic in nature or consisted of fine-tuning or smoothing out the domestic democratic process of some member State. ${ }^{157}$ The more the ECHR and the CJEU are prone to engage in highly contentious issues over which State domestic opinions are deeply divided - such as civil rights, family law, or discriminatory practices- the more they are likely to be seen as endangering the social glue across member States.

The pilot judgment of the ECHR and the preliminary ruling procedure are not byproducts of the two courts' legal doctrines, but their utilization within highly disputed issues raises the question of whether the EU and the Council of Europe can afford having a CJEU or a ECHR that operates undermining the connective tissues of the national communities that compose them.

\section{E. The constitutionalization of supranational judicial trends}

An additional factor that motivates the populist call for the re-statalization of EU policies is the process of constitutionalization of the two pan-European courts' jurisprudence. When the CJEU and the ECHR spell out a certain reading of the EU law and of the ECHR, that reading attaches to the text itself, reaching a high level of stability and resilience that cannot be easily undone. ${ }^{158}$ Through the doctrine of living instrument, the ECHR works by accumulating rights and building upon its jurisprudence, broadening the scope of its Convention. Similarly, as Dieter Grimm has noted, ${ }^{159}$ the CJEU has glossed over EU law with its judgments. This process has not just deprived the political branch of its importance, but the CJEU's case law has also frozen much of the EU's legal framework. ${ }^{160}$

This phenomenon is understandable in light of the two courts' progressive reading of history, which sees a trajectory of improvement through time. Once judicially sanctioned, a right or an issue is removed from the political fore because the overarching theory of contemporary constitutionalism tends to consider the case law as unidirectional.

\footnotetext{
${ }^{154}$ Weiler, supra note 30 , at 103 (saying that "in more than 80 percent of the cases, [the preliminary reference] is a device for judicial review of member state compliance with their obligations under the Treaties.").

${ }^{155}$ Weiler, supra note 37 , at 691.

${ }^{156} I d$.

${ }^{157}$ DALY, supra note 121 , at $112,115$.

${ }^{158}$ Symposium, supra note 45 , at 326 ("When the court is called on to interpret the treaties, it is difficult if not impossible to override a decision of the [CJEU].”); see also SUSANNE K. SCHMIDT, supra note 56, at 93.

${ }^{159}$ See Dieter Grimm, The Democratic Costs of Constitutionalisation: The European Case, 21 EuR. L.J. 460, 470 (2015).

${ }^{160}$ Jeff A. King, Institutional Approaches to Judicial Restraint, 28 OXFORD J. LEGAL STUD. 409, 413 (2008) (warning about the lack of judicial restraint on the part of the then-European Court of Justice).
} 
Some have maintained that the CJEU's linear approach finds confirmation and encouragement in the fact that "there has been essentially not a single case in which an interpretation or a ruling of the [CJEU] has been explicitly overruled through the process of treaty revision, which allows the member states in their capacity as master of the treaties to amend the constitutional arrangement of the EU." ${ }^{161}$ Nevertheless, the mere fact that the States tend not to overrule the CJEU's decisions does not say too much in itself about the appropriateness of a single CJEU judgment or whether the judicial development of EU law is always appropriate. States may decide not to overrule the CJEU's case law for a series of reasons that have nothing to do with the quality of its judgments. Once the case law has become acquis communautaire, changing it would possibly disrupt the process of integration within the EU and unsettle issues that have already been resolved. Unsettling the existing acquis communautaire is particularly unlikely in the huge field of EU law that controls economic activities, ${ }^{162}$ as predictability is a core value for markets. It was for this reason the English doctrine of stare decisis reached its peak in the nineteenth century's eve of economic liberalism. ${ }^{163}$ There is an even simpler explanation for the Treaty's deference towards the CJEU's established case law: Once the CJEU has spoken, a Treaty provision may alter it only with the agreement of all the Member States, which is difficult to achieve and a time-consuming exercise. In other words, the simple fact that the Member States hardly contradict the CJEU does not make its judicial philosophy more apt than any alternative.

The constitutionalization of EU law and the incorporation of the ECHR's interpretation into its Convention have been able to push democratic debates in the relevant matters to the sidelines. ${ }^{164}$ The CJEU and the ECHR's case law do not ossify, because they adopt the idea of progress as their dominant judicial philosophy. ${ }^{165}$ They do tend to deprioritize the role of democratic institutions and the manifestations of the will of the States to the periphery of their legal narratives. ${ }^{166}$

\section{F. Conclusion}

This Article has analyzed the shift that occurs when transnational or supranational courts develop their legal systems according to a judicial philosophy that prizes justification over deliberation and progress over time-consistency in a political scenario of widening ideological rifts. These features of the contemporary trends in the CJEU and ECHR's case law do not simply represent the logical consequence of the institutional mechanisms through which the EU and the Council of Europe operate. Rather, they stem from the judicial doctrines that the two courts adopt.

The judicialization of political choices does not simply shift where decisions are made; it also changes the lexicon of the public discourse. Judicialization translates cultural, ideological, and political issues into arguments that are based on precedents and laws. ${ }^{167}$ By de-politicizing the language, "[d]ecisions of great political impact are taken in a non-political mode."168 If, with

\footnotetext{
${ }^{161}$ Federico Fabbrini \& Miguel Poiares Maduro, Supranational Constitutional Courts, in MAX PlANCK ENCYCLOPEDIA OF Comparative Constitutional Law (2017).

${ }^{162}$ Takis Tridimas, Precedent and the Court of Justice: A Jurisprudence of Doubt?, in PhilosophiCAL Foundations of EURopean Union LAW 312 (Julie Dickson \& Pavlos Elefheriadis eds., 2012).

${ }^{163}$ Franz L. Neumann, The Rule of Law: Political Theory and the Legal System in Modern Society 252-53 (1986).

${ }^{164}$ Yowell, supra note 112, at 130; see also David Prendergast, The Judicial Role in Protecting Democracy From Populism, in this issue (emphasizing the importance of pluralism and of allowing today's losers to gear up and try to become tomorrow's winners through democratic competition, although he targets populists for threatening pluralism: “Today's losers could be tomorrow's winners. In this way, democracy is offended by populism's antipluralism”).

${ }^{165}$ Andrea Pin, Precedente e Mutamento Giurisprudenziale 244-45 (2017).

${ }^{166}$ See also Marco Dani, supra note 123, at 413 (warning that the EU's “institutional architecture," although "renovated," retains "its post-political character").

${ }^{167}$ Waldron, supra note 111 , at 1353.

${ }^{168}$ Grimm, supra note 160 , at 471 .
} 
Robert Cover's words, "[t]o inhabit a nomos is to know how to live in it,"169 the nomos that pan-European legal systems produce, and which replaces national debates and rules, runs the risk of being incomprehensible to many of their inhabitants who are not versed in legalese and therefore may not feel comfortable with it. ${ }^{170}$

The language barrier aggravates the distance between the judiciary and those who are affected by judicial decisions. At the ECHR even "the applicant party will often not be able to read the judgment because it is rendered in either French or English." 171 The formulaic, dry, redundant, and highly technical prose of the CJEU keeps average readers distant, notwithstanding the wide ramifications of its case law. ${ }^{172}$

The gap between the people and the courts creates a disconnect in the very meaning of justification. If justifications are often inaccessible even for those who are directly involved in the proceedings, then the judges, albeit model reason-givers, are nonresponsive-not just to the population, but, more narrowly, to the parties that seek to resolve their dispute. The two courts' advantage in being composed of selected experts with highly sophisticated skills runs the risk of being useless if individuals feel disenfranchised by the overriding judgments of two courts that they hardly understand.

The disconnect between the courts and the Europeans, combined with the replacement of parliamentary deliberation with judicial justification and the ideal of progress, may trigger a sense of inferiority or superiority that can exacerbate social tensions. ${ }^{173}$ Progress can be defined as a process of incremental awareness, prosperity, and a sense of justice, but if the courts are advantageously positioned to identify what constitutes progress in a given circumstance, then their decisions can unilaterally create ideological rankings that determine what is at the top or at the bottom of the scale of progress. In other words, the narrative of progress may not just disempower the popular will, but it can also harm social cohesion by prompting a sense of superiority or resentment, depending on whether one's claim has been judicially affirmed or denied. It therefore comes with little or no surprise that "those parties that most successfully appeal to the interests and fears of the 'losers' of globalization" are the "driving force of the current transformation of the Western European party systems" 174 and of political scenarios.

The prevailing judicial doctrines of the ECHR and the CJEU have both configured into the Council of Europe and EU's historical success, as well as their democratic deficiencies. This Article has argued that supranational European courts are partially responsible for the supranational malaise and the rise of populism in the Old Continent and that the courts can contribute to the recovery of supranational constitutional projects by amending their legal doctrines on the relationship between human rights, democracy, and progress. The default position would consist of abandoning an idea of progress that, as a self-fulfilling prophecy, invites legal development through judicial decisions at the expense of political deliberation, and even fierce disagreement. ${ }^{175}$ A more sound understanding of the proper role of the judiciary should revitalize the public discourse by making room for deliberations, inviting pluralism, and including the narratives of

\footnotetext{
${ }^{169}$ Robert Cover, The Supreme Court, 1982 Term - Foreword: Nomos and Narrative, 97 HaRV. L. Rev. 4, 6 (1983).

${ }^{170}$ Waldron, supra note 111 , at 1353.

${ }^{171}$ Janneke Gerards, The European Court of Human Rights, in Comparative Constitutional ReAsONING 237, 267 (András Jakab, Arthur Dyevre \& Giulio Itzcovich eds., 2017).

${ }^{172} \mathrm{G}$. Federico Mancini, The Making of a Constitution for Europe, 26 COMMON MKT. L. REv. 595, 606 (1989); ElinA Paunio, Legal Certainty in Multilingual EU Law: Language, Discourse and Reasoning at the European COURT OF JUSTICE 19 (2013).

${ }^{173}$ Zoran Oklopcic, Imagined Ideologies: Populist Intarnations, Liberalist Projections, and the horizons of Constitutionalism, in this issue (noting that "Salvini's point remains untranslatable into the idiom of contemporary constitutionalism.")

${ }^{174}$ Hanspeter Kriesi, Edgar Grande, Romain Lachat, Martin Dolezal, Simon Bornschier \& Timotheos Frey, Globalization and the Transformation of the National Political Space: Six European Countries Compared, 45 EUR. J. POL. RES. 921,929 (2006).

${ }^{175}$ Uitz, supra note 5 , at 300.
} 
dissonant voices that disagree with the prevailing narratives of progress and equality as nondiscrimination. ${ }^{176}$

A change in the judicial doctrines of the CJEU and of the ECHR should include a clearer distinction between the scope of the judiciary and the place of domestic and supranational political bodies. More precisely, it seems necessary that the ECHR and the CJEU reconsider the role of the judiciary in securing legal development and progress without disempowering the democratic process, as well as become sensitive to the types of interests involved in each litigation. Economic, social, identitarian, political, and religious conflicts have different ramifications and can hardly be treated with the same legal doctrine.

Such changes cannot be achieved simply through re-engineering supranational institutions. Actually, any re-engineering would hardly be as effective as self-reformation in the judicial style carried out by the courts themselves. In a few words, the CJEU and the ECHR are still the main drivers of the supranational constitutional project, and they can bring it back on track, probably even more effectively and easily than democratically elected institutions could do.

\footnotetext{
${ }^{176}$ Bogdandy, supra note 47 , at 21 .
}

Cite this article: Pin A (2019). The transnational drivers of populist backlash in Europe: The role of courts. German Law 